\title{
Influence of Perceived Organizational Support and Leader-Member Exchange towards Readiness for Change among Employees of PT. Bank X
}

\author{
Vera Nova, Zulkarnain, Sherry Hadiyani \\ Psychology Faculty: Industrial \& Organization Psychology \\ Sumatera Utara University \\ Medan, Indonesia \\ veranova.mp2@gmail.com
}

\begin{abstract}
This study aims to determine the influence of perceived organizational support and leader-member exchange to readiness for change among employees of PT. Bank X. The measurement tools used in this research were perceived organizational support scale, leader-member exchange scale and readiness for change scale. The study involved 293 employees of PT. Bank X. The sampling method used is stratified random sampling. The statistical analysis used is multiple regression analysis. The results showed that perceived organizational support and the leader-member exchange influenced towards readiness for change among employees of PT. Bank X. Perceived organizational support and leader-member exchange contributed positively to employees' readiness for change. Perceived organizational support morecontributed to increasing readiness for change among employees of PT. Bank X rather than leader-member exchange. The implications of this research for the company to provide more support for the employees and implemented a better leader-member exchange in the company, so that the employees will be more ready to change.
\end{abstract}

Keywords:Perceived Organizational Support; Leader-Member Exchange; Readiness for Change; Bank Employee.

\section{INTRODUCTION}

The need for a banking system that meets the Islamic Shari'a law is increasing in Indonesia lately, as well in the $\mathrm{X}$ Province which the majority of the people are Muslim. It also became one of the reasons PT. Bank X in X Province took a strategic step to convert its banking business from conventional system to sharia system, as an effort to meet the expectations and desires of the people who want a more calming, lawful banking system and by the principles of Islamic Sharia.

Changes made cannot be separated from the pro and contra of various parties that involved in the circumstances, and this condition certainly has an impact on the company. Any changes occurring within the corporate environment must be carefully examined because the effectiveness of the changes depends on the extent to which all components within the company can adapt to those changes so that the goal of change can be achieved as expected [1].

Companies must be very careful in implementing the change because if the process fails, it will cause risk and negative effects in both the short and long term [2]. The risks should be addressed by the organization. Therefore management and leaders within the organization must be able to establish, manage and measure staff readiness for change so that the implementation of the change can work effectively. The success of the changes can only occur if employees are willing to devote the time and energy necessary to achieve these changes [3].

Organizational changes will not be working without employee changes, and employee changes are ineffective without being prepared in advance, as employees are the most important element for organizational success [4]. Organizations that will make changes require employee support openly, prepare well, and be ready to change [5]. Improving the readiness for change of all employees is one of the most effective interventions that an organization can make [6]. When the employees are not ready to change, they are unable to follow and will feel overwhelmed by the changes that are taking place within the organization. The employee's un-readiness has a negative impact on organizational change [7].

Several previous studies have explained that positive perceptions of employees to the support that organizations provide to them affect the quality of their working lives and will create a sense of "debt of gratitude" to the organization so that they will feel obligated to pay [8]. Workers who feel that they are supported by the organization will provide positive feedback. Employees who believe that the organization will provide some valuable resources for their career development such as training and job security opportunities tend to have a more positive 
perceived organizational support than those who see the opportunity as a mere promise [9].

Also, the interaction relationship built up within the organization among all employees is also believed to be one of the predictors of readiness to change, which the interaction quality of subordinate and superiors commonly known as Leader-Member Exchange (LMX)). Riggio[10]Stated that if the query of leadermember exchange is high, then the boss will have apositive view to his subordinates so that subordinates will feel that his boss gives support and motivation. Leader-member exchange will also have a positive impact such as increased productivity, job satisfaction, and employee performance. Research from Konovsky \& Pugh[11] suggests that a good boss will encourage employees to behave positively because of the good relationship between subordinates and superiors. Also, individual beliefs and beliefs about leaders or management are one dimension of readiness for change, where employees who have confidence that leaders will support and commit to proposed changes will employ employees to provide support to the organization, one of which is ready to support change [12];[13].

\section{METHOD OF RESEARCH}

The variables in this study are readiness for change as thedependent variable, perceived organizational support and leader-member exchange (LMX) as theindependent variable.

\section{RESEARCH SUBJECT}

This research was conducted on employees of PT. Bank X. There are 293 subjects of the research, with the characteristics: permanent employees of 5 classes of positions, they are Clerk, Officer, Assistant Manager, Manager and Vice President.

\section{MEASURING INSTRUMENT}

This study was conducted using some scales to measure the level of perceived organizational support, the level of perceived leader-member exchange (LMX) and the level of employee readiness for change. The scales used are as follows:

\section{A. Readiness for Change Scale}

The scale used is the scale of readiness for change based on the dimensions of readiness for change proposed by Holt et al.[14], namely (1)
Appropriateness, (2) Management Support, (3) Personal Benefit and (4) Change Specific Efficacy.The scale model used in this research is Likert scale [15], with four choices of answers are: Strongly Disagree (STS), Disagree (TS), Agree (S), and Strongly Agree (SS). This scale is composed of 14 point statements. The results of reliability analysis using Cronbach Alpha technique obtained reliability coefficient value of 0.898 .

\section{B. Perceived Organizational Support Scale}

The scale used is the scale of perceived organizational support based on aspects of organizational support perception proposed by Rhoades \& Eisenberger[16], namely: (1) Supervisor Support, (2) Procedural Justice, (3) Organizational Reward and Working Condition. The scale model used in this research is Likert scale [15], with four choices of answers are: Strongly Disagree (STS), Disagree (TS), Agree (S), and Strongly Agree (SS). This scale is composed of 15 point statements. Results of reliability analysis using Cronbach Alpha technique obtained reliability coefficient value of 0.843 .

\section{Leader-Member Exchange (LMX) Scale}

The scale used is the leader-member exchange scale based on LMX dimension proposed byLiden\& Maslyn[17], namely: (1) Affect, (2) Loyalty, (3) Contribution, and (4) Professional Respect. The scale model used in this research is Likert scale [15], with four choices of answers are: Strongly Disagree (STS), Disagree (TS), Agree (S), and Strongly Agree (SS). This scale is composed of 18 items of statements. Results of reliability analysis using Cronbach Alpha technique obtained reliability coefficient value 0.936 .

\section{ANALYSIS METHOD}

This research uses statistical analysis method. Statistical analysis method used is regression analysis with the help of computer program Statistical Package for Science (SPSS) version 16.0 For Windows.

\section{RESEARCH RESULT}

After testing on the major and minor hypotheses with regression analysis techniques, here are some research results that have been obtained as follows: 


\section{Main Research Results}

In the main hypothesis, there is a very significant positive relationship between the perceived organizational support and leadermember exchange (LMX) with the employees' readiness for change. This can be seen from the correlation coefficient value of 0.461 and $p=$ 0.000 ( $\mathrm{p}<0.05)$. From the value of multiple determination coefficient $(\mathrm{R} 2=0,207)$. Both variables can explain $20.7 \%$ variant of employees' readiness for change in PT. Bank X. Further results of the main hypothesis can be seen in Tables I and II.

TABLE I. CORRELATION COEFFICIENT INFLUENCE OF POS AND LMX TOWARDS RFC

\begin{tabular}{|l|c|c|r|r|}
\hline $\begin{array}{l}\text { Mod } \\
\text { el }\end{array}$ & $\mathbf{R}$ & $\begin{array}{c}\text { R } \\
\text { Squar } \\
\mathbf{e}\end{array}$ & $\begin{array}{l}\text { Adjusted } \\
\text { R Square }\end{array}$ & $\begin{array}{c}\text { Std. Error of } \\
\text { the } \\
\text { Estimate }\end{array}$ \\
\hline 1 & $\begin{array}{r}.461 \\
\mathrm{a}\end{array}$ & .212 & .207 & 5.093 \\
\hline
\end{tabular}

a. Predictors: (Constant), LMX, POS

b. Dependent Variable: RFC

TABLE II. HYPOTHESIS RESULT FOR INFLUENCE OF POS AND LMX TOWARDS RFC

\begin{tabular}{|l|l|c|c|c|c|c|}
\hline \multicolumn{2}{|l|}{ Model } & $\begin{array}{c}\text { Sum of } \\
\text { Square } \\
\text { S }\end{array}$ & df & $\begin{array}{c}\text { Mean } \\
\text { Squar } \\
\text { e }\end{array}$ & F & Sig. \\
\hline 1 & $\begin{array}{l}\text { Regress } \\
\text { ion }\end{array}$ & $\begin{array}{c}2026.68 \\
8\end{array}$ & 2 & $\begin{array}{c}1013 . \\
344\end{array}$ & $\begin{array}{c}39.06 \\
7\end{array}$ & $\begin{array}{c}.00 \\
0 \text { a }\end{array}$ \\
\cline { 2 - 7 } & $\begin{array}{l}\text { Residua } \\
1\end{array}$ & $\begin{array}{c}7522.25 \\
4\end{array}$ & 290 & 25.93 & & \\
& 9 & & \\
\hline Total & $\begin{array}{c}9548.94 \\
2\end{array}$ & 292 & & & \\
\hline
\end{tabular}

a. Predictors: (Constant), LMX, POS

b. Dependent Variable: RFC

\section{E. Additional Research Results}

In the additional hypothesis obtained a significant positive relationship between the perceived organizational supports with readiness for change. This can be known from the partial R-value $=0.449$ and $\mathrm{p}=0.000 \mathrm{(p}$ $<0.05$ ), meaning that the stronger organizational support is perceived by the employee, the more employees are ready for achange. The results can be seen from tables III and IV.
TABLE III. CORRELATION COEFFICIENT INFLUENCE OF POS TOWARDS RFC

\begin{tabular}{|l|c|c|c|c|}
\hline $\begin{array}{c}\text { Mode } \\
\text { I }\end{array}$ & $\mathbf{R}$ & $\begin{array}{c}\text { Rquar } \\
\text { e }\end{array}$ & $\begin{array}{c}\text { Adjuste } \\
\text { d R } \\
\text { Square }\end{array}$ & $\begin{array}{c}\text { Std. Error } \\
\text { of the } \\
\text { Estimate }\end{array}$ \\
\hline 1 & .44 & .202 & .199 & 5.118 \\
\hline
\end{tabular}

a. Predictors: (Constant), POS

b. Dependent Variable: RFC

TABLE IV. HYPOTHESIS RESULT FOR INFLUENCE OF POS TOWARDS RFC

\begin{tabular}{|l|l|r|r|r|r|r|}
\hline \multicolumn{2}{|c|}{} & $\begin{array}{c}\text { Sum } \\
\text { of } \\
\text { Squar } \\
\text { es }\end{array}$ & Df & $\begin{array}{c}\text { Mean } \\
\text { Square }\end{array}$ & \multicolumn{1}{|c|}{ F } & Sig. \\
\hline 1 & $\begin{array}{l}\text { Regress } \\
\text { ion }\end{array}$ & $\begin{array}{r}1925 . \\
709\end{array}$ & 1 & 1925.70 & 73.51 & .000 \\
& Residua & 7623. & 29 & 0 & $\mathrm{a}$ \\
& 233 & 1 & 26.197 & & \\
& Total & 9548. & 29 & & & \\
& 942 & 2 & & & \\
\hline
\end{tabular}

a. Predictors: (Constant), POS

b. Dependent Variable: RFC

From the results of additional research, also found a significant positive relationship between perceived of leader-member exchange (LMX) with readiness for change. This can be known from r-partial $=0.137$ and $p=0.000(p<0.05)$, meaning that the better leader-member exchange (LMX) perceived by the employee, the more employees are ready for achange. The results of this minor hypothesis can be seen in table V and VI.

TABLE V. CORRELATION COEFFICIENT INFLUENCE OF LMX TOWARDS RFC

\begin{tabular}{|l|c|r|r|r|}
\hline $\begin{array}{l}\text { Mod } \\
\text { el }\end{array}$ & $\mathbf{R}$ & $\begin{array}{c}\text { R } \\
\text { Square }\end{array}$ & $\begin{array}{l}\text { Adjusted } \\
\text { R Square }\end{array}$ & $\begin{array}{l}\text { Std. Error of } \\
\text { the Estimate }\end{array}$ \\
\hline 1 & $.370^{\mathrm{a}}$ & .137 & .134 & 5.321 \\
\hline
\end{tabular}

a. Predictors: (Constant), LMX

b. Dependent Variable: RFC

TABLE VI. HYPOTHESIS RESULT FOR INFLUENCE OF LMX TOWARDS RFC

\begin{tabular}{|c|c|c|c|c|c|}
\hline Model & \begin{tabular}{|c|} 
Sum \\
of \\
Squar \\
es
\end{tabular} & df & $\begin{array}{c}\text { Mean } \\
\text { Square }\end{array}$ & $\mathbf{F}$ & Sig \\
\hline $1 \mid \begin{array}{l}\text { Regress } \\
\text { ion }\end{array}$ & $\begin{array}{r}1308 . \\
369\end{array}$ & 1 & $\begin{array}{r}1308.36 \\
9\end{array}$ & $\begin{array}{r}46.2 \\
03\end{array}$ & .00 \\
\hline
\end{tabular}




\begin{tabular}{|l|l|r|l|l|l|l|}
\hline Residua & 8240. & 291 & 28.318 & & \\
\hline Total & 9548. & 292 & & & \\
& 942 & & & & \\
\hline
\end{tabular}

a. Predictors: (Constant), LMX b. Dependent Variable: RFC

Perceived organizational support variable hasa greatereffective contribution to the improvement of readiness for change of employees that is equal to $15.8 \%$, then followed by leader-member exchange (LMX) variable $4.9 \%$. The total effective contribution of perceived organizational support (POS) and leader-member exchange (LMX) together to readiness for change (RFC) is $20.7 \%$, whereas $79.3 \%$ comes from other variables which cannot be explained in this research which allegedly influences employees' readiness for change.

\section{DISCUSSION}

The main hypothesis of this study mentions that there is a correlation between the perceived organizational support and the leader-member exchange (LMX) with the employees' readiness for change. The result of the regression analysis shows that the hypothesis is accepted. It can be seen from the correlation coefficient value of $0.461, \mathrm{p}=0.000(\mathrm{p}<0.05)$ on table I and II. This means that the perceived organizational support and the leader-member exchange (LMX) together influenced the employees' readiness for change.

The results of this study are in line with the opinion of Robbins [1] who said that the attitude or behavior of members of the organization, in general, is influenced by the value system adopted in the organization and also influenced by the behavior of leaders, including in this case the attitude of employees of PT. Bank X in facing the conversion. Organizational support variable as well as leader role in PT. Bank X simultaneously proved to have a significant positive effect on employee readiness for change. It is as Stewart[18] argues that there are 17 (seventeen) key elements of the diagnosis of change by using the Readiness for changes model, where two elements of which are organizational factors and role leaders [19]. Goodman, Devadas \& Hughson [20]also found evidence that collaboration of all components within the organization can develop organizational outcomes in a variety of situations, including in change situations.
In addition Research conducted by Rafferty, Jimmieson \& Armenakins[21] identifies some antecedents of readiness for change at the individual level, where the main antecedents of employees' readiness to change originate from the organizational internal context, namely leadership roles and individual perceptions of organizational contexts (including communication, organizational support, value and value alignment -organizational values).Perception of PT. Bank X employees on the ability of enterprises and management to face changes greatly affect their opinion about the conversion made by PT. Bank X. Employees of PT. Bank $X$ believes that firms and management have a good enough ability to deal with conversions so that they feel they are capable of confronting these conversions with the support from companies and management.

Besides, Armenakins et al[22] and McManus et al [23] also found that the level of trust in organization and management can lead to positive perceptions of organizational speed in the face of change, where good planning for change cannot be accomplished without the support of agents' capabilities and commitments for changes included from the leaders.Confidence of the leaders of PT. Bank X to be able to manage change in the organization becomes an important key to the confidence development of employees on the success of the program and will encourage employees' readiness for change. Confidence of PT. Bank X employee that their leaders can manage conversions well is an important foundation for employees' growing confidence in the success of the conversion program.

The first additional hypothesis proves that there is a positive correlation between perceived organizational support and employee readiness for change. Partial analysis results show acceptable hypothesis. It can be seen from the partial correlation coefficient ( $\mathrm{r}$-partial) $=0.449$, $\mathrm{p}=0.000(\mathrm{p}<0.05)$ in table III and IV. It means that the stronger organizational support is felt by the employee, the more employees are ready for achange. The results of this study indicate that the employees' perception of organizational support they are received from the company; especially during the conversion process conducted by PT. Bank X is an important aspect of their change readiness. In fact, the conversion made by PT. Bank X is highly dependent on the readiness of all components in the company to accept the change, including the readiness of 
employees for change. So it becomes an important thing for PT. Bank X to prepare the employees facing the conversion by providing strong support in various aspects that employees need.

Building a readiness for change among employees who are familiar with old patterns and having to learn new ways of working is not easy [24]. This is because every employee has a difference in assessing and looking at new circumstances encountered. Assessment and outlook of each employee will bring an attitude in the employee, both positive and negative attitude. Employees who are ready to change will find it easier to initiate change, exert greater effort in supporting change, and show perseverance to face obstacles or constraints during the implementation of the change [2]; [4];[25].

Chun \& Tsung[26]stated that organizational support could improve the performance of its members, where the performance will produce a very significant influence on organizational success, including success in the face of change. This is in line with the opinion of Beckhardt \& Harris[27] which says that the support provided by the organization can be a clear policy, procedure and logistic support system (equipment, monetary resources, etc.) will make employees feel the certainty and clarity of their work.Also, support can also be reflected in how the organization and management accommodate changes throughreorganization, performance evaluation, and compensation both material and socio-emotional to employees. The Employees who feel the clarity and certainty of the work they do will be more ready to face the change.

The second additional hypothesis proves a positive correlation between the leader-member exchanges with employees' changing readiness. Partial analysis results show acceptable hypothesis. This can be seen from the partial correlation partial $(\mathrm{r}$-partial) $=0.137$ and $\mathrm{p}=$ $0.000(p<0.05)$ in table $V$ and IV. The meaning is the better leader-member exchange perceived by the employee; the more employees are ready to change.

From the results of the research noted that the leaders who can build strong and reliable relationships by subordinates empathize, and inspirational, and able to integrate financial assets, human, intellectual, social, theenvironmentwouldbe a driver to achieve a synergy that can improve organizational effectiveness [28]. Armenakins \& Harris[29]also reinforce that one of the important factors of organizational change, but also the least understood, one of which is the skill of leaders.

Leaders at PT. Bank X which are the agent of change founded that quite capable of performing its role in motivating and supporting its employees during the conversion process. Leaders at PT. Bank X is perceived to be able to build good, positive interaction relationships and create a supportive working environment for employees, thereby positively affecting employee readiness in facing the conversion. This is by the results of research that also found that leadermember exchange (LMX) will greatly affect the readiness of employees for change [30].

One of the reasons why leader-member exchange (LMX) affected readiness for change was due to the positive feelings and perceptions that arise among the employees about the quality of good interaction between them with their boss. Positive feelings and perceptions among employees of PT. Bank X in their interactions with the boss fosters the trust and commitment of employees, so the boss will be easier to influence the beliefs, attitudes, and behaviors of change targets (employees of PT Bank X) and increase their motivation to change [31].

Kalyaret al.[32] and Lo et al.[33] also added that leaders could play an important role in organizational change that will impact on employees' commitment and readiness for change in facing the organizational change. Graen \& Bien[34]Also said that with a mature leadership relationship (good LMX), superiors and subordinates experience mutual influence, extra-contractual behavior, mutual respect, and likes, and caninternalize the same goals, including in this case readiness for change in conversion circumstances.

\section{SUGGESTION}

Based on the results of data analysis and discussion, theauthor put forward some suggestions as follows:

1. Employees' perceived perceptions of support given by the organization are in the medium category. This means that PT. Bank X needs to improve the support that has been given to employees so that employees can better prepare for change. Support can be given by providing information, facilities, improvement of knowledge and adequate skill to do they 
work. The support should be given continuously to the employees doing they work optimally so they will have sustainable capacity and capability in facing the conversion.

2. The perception of leader-member exchange (LMX) is perceived in good category by employees of PT. Bank X, so it is necessary for PT. Bank $X$ to maintain the quality of interaction of existing subordinate supervisors, including providing further provisioning to the leaders about the importance role of the leaders in building good quality relationships and positive circumstances with the employees for the success of conversion made PT. Bank X. The provisioning can be held invarious forms such as training, workshop, coaching and other relevant methods.

3. Average employees of PT. Bank X is ready for achange. So it is necessary for PT. Bank X to maintain all aspects that able to enhanced and supported employee readiness for change, including engaging employees actively in the change process and change circumstances.

4. The total effective contribution simultaneously of perceived organizational support variables and leader-member exchange (LMX) to readiness for change is $20.7 \%$, while $79.3 \%$ comes from other unexplained variables. Therefore it is necessary to do more research by involving other variables that affectemployees' readiness for change.

5. Scale distribution should be done directly to the research respondent, and if necessary can be accompanied in thefilling process to avoid misunderstanding and bias in filling the scale.

\section{REFERENCES}

[1] Robbins, S. P. Organizational behavior: concepts, controversies, applications. Englewood Cliffs, NJ: Prentice-Hall, 2001.

[2] Petterson, S. Organizational change management: Getting from here to there. USA: Knowledge Peak, 2009

[3] Simbolon, R., \& Anisah, H. U. Influence of organizational change and organizational culture on employee performance: Study at State Wealth Service Office and Auction (KPKNL) InsightsManagementJournal. (Pengaruh perubahanorganisasi dan budayaorganisasiterhadapkinerjapegawai:
Studi pada Kantor Pelayanan Kekayaan Negara dan Lelang (KPKNL) Banjarmasin. Jurnal Wawasan Manajemen),1(1), 1-20, 2013.

[4] Madsen, S. R., John, C. R., \& Miller, D. Readiness for organizational change: Do organizational commitment and social relationship in the workplace make a difference. Human Resources Development Review, 12(2), 93-110, 2005.

[5] Eby, L. T., Adams, D. M., Russel, J. E. A., \& Gaby, S. H. Perceptions of organizational readiness for change: Factors related to employees' reactions to the implementation of team-based selling. Journal of Human Relations, 53(3), 419-442, 2000.

[6] Cunningham, C. E., Woodward, C. A., Shannon, H. S., Macintosh, J., Lendrum, B., Rosenbloom, D., \& Brown, J. Readiness for organizational change: A longitudinal study of workplace, psychological and behavioral correlates. Journal of Occupational and Organizational Psychology, 75, 377-392, 2002.

[7] Ciliana, \&Mansoer, W. D. The influence of job satisfaction, job involvement, work stress and organizational commitment to readiness for change on employees of PT. Bank Y. Journal of Social Psychology. (Pengaruh kepuasankerja, keterlibatankerja, stress kerja dan komitmenorganisasiterhadapkesiapanuntu kberubah pada karyawan PT. Bank Y. Jurnal Psikologi Sosial), 14(2), 151-164, 2008

[8] Rhoades, L., Eisenberger, R., \&Armenali, S. Affective commitment to organization: the contribution of perceived organizational support. Journal of Applied Psychology, 86, 825-836, 2001.

[9] Eisenberger, R., Sucharski, I. L., \& Jones, J. R. Perceived organizational support.(In J. Coyle-Shapiro, L. Shore, \& S. Taylor, \& L. Tetrick Ed.). The employment relationship: Examining psychological and contextual perspectives (pp. 206-225). New York: Oxford University Press, 2004..

[10] Riggio, R. E. Introduction to industrial/organizational psychology. Illinois: Scott, Foresman and Company, 1990.

[11] Konovsky, M. A. \& Pugh, S. D. Citizenship and Social Exchange. Academy of Management Journal. 37, 656-669, 1994. 
[12] Fuller, J. The influence of empowerment on employee loyalty in a downsizing environment. Journal of Group \& Organization Management, 26, 93-113, 2001.

[13] Periantalo, J., \&Mansoer, W. D. Factors' influencing readiness to change staff at Dir. Pen. PQR. Journal of Social Psychology, University of Indonesia, (Faktor-faktor yang mempengaruhikesiapanuntukberubahpega wai di Dirjen PQR. Jurnal Psikologi Sosial Universitas Indonesia), 14(3), 195-203, 2008.

[14] Holt, D., Armenakins, Field, S., \& Harris, G. Readiness for organizational change the systematic development of a scale. The Journal of Applied Behavioral Science, 43(2), 232-255, 2007.

[15] Azwar, S. Reliability and validity. (Reliabilitas dan validitas). Yogyakarta: Pustaka Pelajar, 2009.

[16] Rhoades, L., \& Eisenberger, R. Perceived organizational support: A review of the literature. Journal of Applied Psychology, 87, 698-714, 2002.

[17] Liden, R. C., \& Maslyn. J. M. Multidimensionality of LMX: An empirical assessment through scale development. Journal of Management, 24(1), 43-72, 1998.

[18] Stewart, A. M. Empowering people. London. Postman Publishing, 1994.

[19] Palmer I., et al. Managing organizational change. New York, Amerika: McGrawhill, 2009.

[20] Goodman, P. S., Devadas, R., \& Hughson, T. L. Groups and productivity: analyzing the effectiveness of self-managing teams. In J. P. Campbell and R. J. Campbell (eds.)productivity in organizations: New perspectives from industrial and organizational psychology. San Francisco: Jossey-Bass, 1988.

[21] Rafferty, A. E., Jimmieson, N. L., \& Armenakis, A. A. Change readiness: A multilevel review. Journal of Management, 39(1), 110-135, 2013.

[22] Armenakins, A. A., Harris, S. G., \& Mossholder, K. W. Creating readiness for organizational change. Journal of Human Relations,46(6), 681-703, 1993.

[23] McManus, S. E., Russell, J. E. A., Freeman, D. M., \& Rohricht, M. T. Factors related to employees' perceptions of organizational readiness for change. Paper presented at the Annual Meeting of the Academy of Management, Vancouver, BC, Canada, 1995.

[24] Soetjipto, D. Determining factors of synergy readiness and strategic behavior of employees post-merger: Case study in SOEs cement. University of Indonesia. (Faktor penentukesiapansinergi dan perilaku strategic

karyawanpascapenggabunganperusahaan: Studi kasus di BUMN semen. Universitas Indonesia. 2009. (unpublished dissertation)

[25] Susanto, A. B. Organizational readiness for change: A case study on change readiness in a manufacturing company in Indonesia. International Journal of Management Perspectives, 1, 50-61, 2008.

[26] Chun, F., \& Tsung, S. H. The impacts of perceived organizational support and psychological empowerment on job performance: The mediating effects of organizational citizenship behavior. International Journal of Hospitality Management, 31, 180-190, 2012.

[27] Beckhardt, R., \& Harris, R. T. Organizational transitions: Managing complex change. Reading: Addison-Wesley, 1987.

[28] Boyatzis, R., \& McKee, A. Resonant leadership. Diterjemahkan oleh: Hikmat Gumelar. Jakarta: Erlangga, 2010.

[29] Armenakins, A. A., \& Harris, S. G. Crafting a change message to create transformational readiness. Journal of Organizational Change Management, 15 (2), 169-183, 2002.

[30] Veronika, T., \& Prihatsanti, U. Relationship between leader member exchange with readiness to change at employee of Tidar University in Magelang. Journal of empathy. (Hubungan antaraleader member exchange dengankesiapanuntukberubah pada pegawai Universitas Tidar di Magelang. Jurnal empati), 6(1), 407-410, 2017.

[31] Applebaum, S.H., \& Wohl, L. Transformation or change: Some prescriptions for health care organizations. Managing Service Quality, 10(5), 279-297, 2000.

[32] Kalyar, M.N., Rafi, N \& Ahmad, B. Organizational learning and organizational commitment: A correlational study in manufacturing context. African Journal of Business Management, 6(9), 3349-3355, 2012. 
[33] Lo, M. C., Ramayah, T., Cyril de Run, E. C., \& Ling, V. M. New leadership, leader-member exchange and commitment to change: the case of higher education in Malaysia. World Academy of Science, Engineering and Technology Review, 53, 574-580, 2009.
[34] Graen, G. B., \& Uhl-Bien, M. Relationshipbased approach to leadership: Development of leader member exchange (LMX) theory of leadership over 25 years: Applying a multilevel multi-domain perspective University of Nebraska, 1995. (Research published in leadership quarterly). 